University of Nebraska - Lincoln

DigitalCommons@University of Nebraska - Lincoln

Entomology Papers from Other Sources

Entomology Collections, Miscellaneous

1988

Insect Succession in a Stored-Corn Ecosystem in Southeast

Georgia

R. T. Arbogast

USDA-ARS, Savannah, Georgia 31403

M. A. Mullen

USDA-ARS, Savannah, Georgia 31403

Follow this and additional works at: https://digitalcommons.unl.edu/entomologyother

Part of the Entomology Commons

Arbogast, R. T. and Mullen, M. A., "Insect Succession in a Stored-Corn Ecosystem in Southeast Georgia" (1988). Entomology Papers from Other Sources. 112.

https://digitalcommons.unl.edu/entomologyother/112

This Article is brought to you for free and open access by the Entomology Collections, Miscellaneous at DigitalCommons@University of Nebraska - Lincoln. It has been accepted for inclusion in Entomology Papers from Other Sources by an authorized administrator of DigitalCommons@University of Nebraska - Lincoln. 


\title{
Insect Succession in a Stored-Corn Ecosystem in Southeast Georgia
}

\author{
R. T. ARBOGAST AND M. A. MULLEN
}

\author{
Stored-Product Insects Research and Development Laboratory,
} USDA-ARS, Savannah, Georgia 31403

\begin{abstract}
Ann. Entomol. Soc. Am. 81(6): 899-912 (1988)
ABSTRACT Insect populations infesting a small bulk of corn stored in southeastern Georgia were followed for $8 \mathrm{yr}$ by monthly sampling beginning 8 mo after the corn was placed in storage. The species composition of the insect community changed as the corn deteriorated. Nine species became dominant at some stage of succession. Sitotroga cerealella (Olivier) was the dominant species when the first sample was taken. It was succeeded a month later by Oryzaephilus surinamensis (L.), which declined rapidly after 2 mo of dominance and died out during the third year. Cryptolestes ferrugineus (Stephens) was dominant at various times during the first 4 yr. Sitophilus zeamais Motschulsky was dominant during the second year and again briefly during the third. Anisopteromalus calandrae (Howard), a hymenopterous parasite of $S$. zeamais, was the most abundant species in one sample taken during the third year. Tribolium castaneum (Herbst) was a significant component of the insect community throughout much of the storage period and was the predominant species during much of the third through fifth years. Latheticus oryzae Waterhouse became dominant during the fifth year, after the grain had become heavily damaged and large quantities of frass, flour, and insect remains had accumulated. It remained the most abundant species for 3 yr. Cynaeus angustus (LeConte) became dominant for a brief period during the eighth year and was succeeded by Trogoderma inclusum LeConte, which was the predominant species when the last sample was taken.
\end{abstract}

KEY WORDS Insecta, population dynamics, community ecology, stored products

STORED GRAIN with its associated organisms and the physical storage environment constitute a moreor-less closed ecosystem in which the grain is the primary energy source. This energy source is nonrenewable and is usually reduced during storage through the action of insects, fungi, and other organisms (Sinha 1973). As grain degrades, the associated biotic community undergoes changes in composition. Good storage practices and the usual duration of storage prevent this process from proceeding very far. However, there are instances in which good storage practices are not used or in which grain is stored for longer than normal periods. Also, in many storage facilities grain residues accumulate in inaccessible places and can remain there for many years. In such situations, succession of insect populations can proceed uninterrupted, and the residues can serve as sources of infestation for newly stored batches of grain. Thus successional changes in insect populations breeding in stored grain are of some practical as well as academic interest.

Our paper describes ecological succession of species populations within an insect community that flourished for $8 \mathrm{yr}$ as part of a stored-corn ecosystem in southeastern Georgia.

\section{Materials and Methods}

A small quantity $(5.36 \mathrm{t})$ of shelled corn was placed in storage at the Savannah Laboratory in
October 1977. The corn originated on a farm in southeastern Georgia and had not been treated with insecticide. The storage structure was an aluminum shed ( 3.4 by $8.8 \mathrm{~m}$ inside) lined with plywood and insulated with $3.8 \mathrm{~cm}$ Styrofoam in the walls and ceiling. The shed had not been used previously for grain storage. The grain was retained by a bulkhead near the front of the shed and covered an area of $24.8 \mathrm{~m}^{2}$ to a depth of about $0.3 \mathrm{~m}$. Wooden walkways above the storage area permitted us to take samples without stepping in the grain.

Our plan was to study the population dynamics of Cadra cautella (Walker). About 4,000 laboratory-reared adults were introduced in April 1978, but when these moths failed to become well established, and large populations of other species became evident, we decided to follow changes in the entire insect community. With the exception of $C$. cautella, the infestation was natural and probably occurred on the farm. Although invasion of the corn by insects after it was placed in storage at Savannah cannot be ruled out, the relative tightness of the shed and its location far from agricultural areas make the farm a more likely source of infestation. The true origin of the C. cautella that persisted throughout most of the study is unknown, and natural infestation cannot be ruled out.

The first sample was taken in June 1978. The sampling plan and procedures were described in detail by Arbogast \& Mullen (1987). Samples were taken at intervals of $30 \mathrm{~d}$ or about 1 lunar month, 

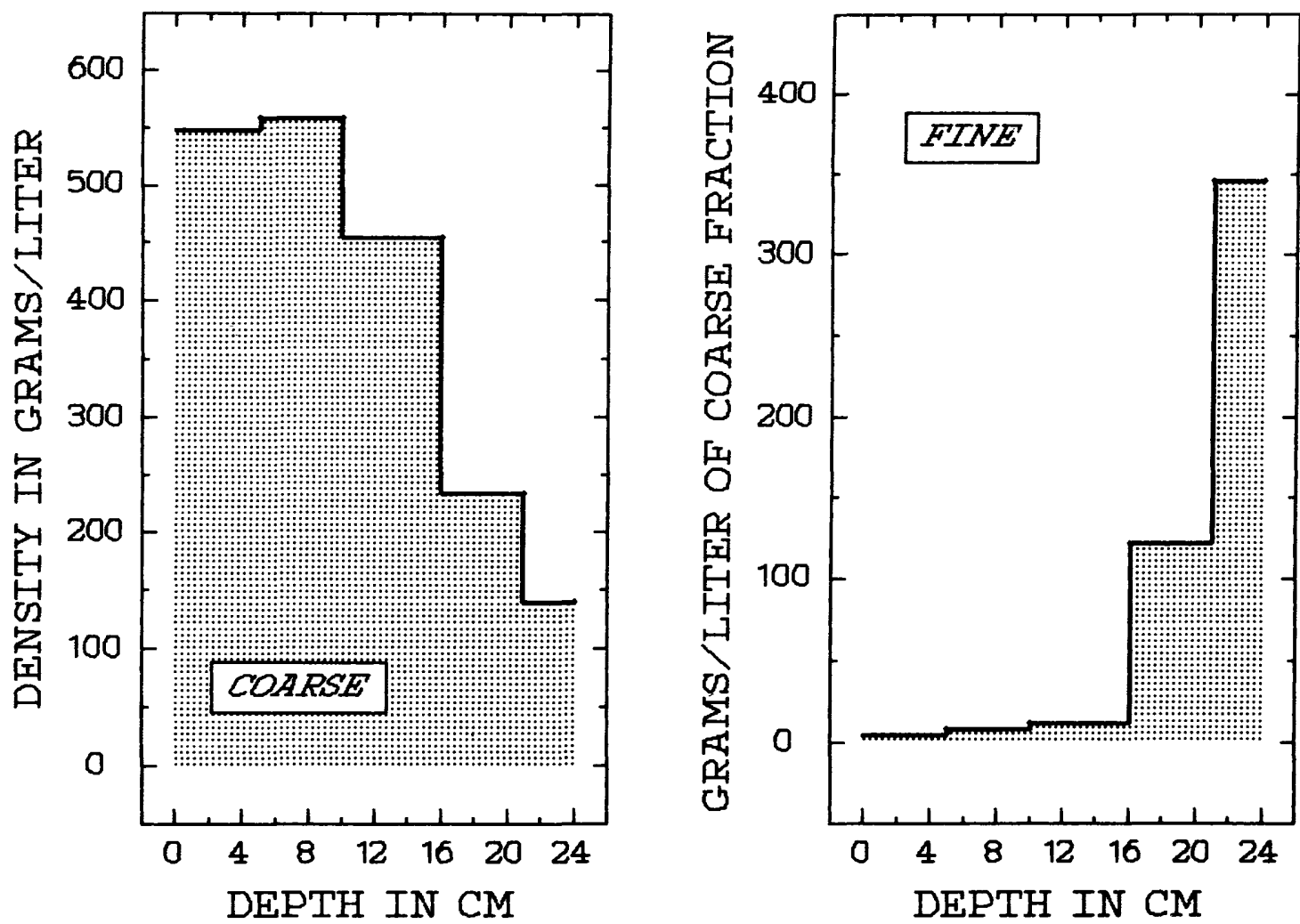

Fig. 1. Relationship between depth within the corn bulk and amount of damage sustained during storage for 46 lunar months, as indicated by density of the coarse fraction (kernel density) in grams/liter and the amount of fine material (flour and frass) in grams/liter of coarse fraction.

and each sample consisted of 48 subsamples ( 400 $\mathrm{ml})$. Because the samples were not returned to the shed, about $23 \%$ of the corn bulk was lost in $8 \mathrm{yr}$ from sampling. Adult insects were removed and counted on the day the samples were taken and again after the samples had been incubated for 1 wk and for 3 wk at $30^{\circ} \mathrm{C}$ and $60 \% \mathrm{RH}$. Analyses were performed on combined counts, which represent a substantial portion of the immature populations as well as the adult populations within the grain bulk. Adult populations in the shed outside the grain bulk were not sampled.

Profiles of grain damage were determined at one or two points in the grain mass after 46,58 , and 82 lunar months storage time by pushing a metal cylinder ( $15 \mathrm{~cm}$ diameter) through the grain to the floor and scooping out the contents. Insect feeding results in hollowing out and reduction in size of grain kernels and in accumulation of fine dust consisting of frass and grain fragments. The ratio of weight to volume of a grain sample after sieving off the fine material (density of coarse fraction or kernel density) and the weight of fine material per unit volume of coarse fraction provide measurements of grain degradation. The methods used in making these measurements were described by Arbogast \& Mullen (1987).
In describing results, the term abundance is used synonymously with mean population density (mean number of insects per subsample) and its log transform. Relative abundance refers to the proportion (or percentage) of a species in the total insect population and is thus a measure of the importance of a particular species (in terms of numbers) in the population. Standard errors for relative abundance were estimated using the normal approximation (Cochran 1977). The dominant species at any given time is the species with the greatest relative abundance.

Unless otherwise acknowledged, all insects were identified by the senior author. Voucher specimens (except for Lepidoptera) have been deposited in the U.S. National Museum of Natural History, Washington, D.C.

\section{Results}

Deterioration of the corn during 97 mo of storage was described by Arbogast \& Mullen (1987). Kernel density of corn near the surface decreased from 786 to $390 \mathrm{~g} /$ liter. Damage increased with depth, and near the bottom, the grain was eventually reduced to dust and fragments. The relationship between depth within the bulk and damage is illus- 
Table 1. Insect fauna of a small bulk of shelled corn stored for 8 yr at Savannah, Ga.

\begin{tabular}{|c|c|}
\hline Order/family & Species \\
\hline Psocoptera & Unidentified \\
\hline \multicolumn{2}{|l|}{ Coleoptera } \\
\hline Dermestidae & Trogoderma inclusum LeConte \\
\hline \multirow[t]{2}{*}{ Cucujidae } & Cryptolestes ferrugineus (Stephens) \\
\hline & Oryzaephilus surinamensis (L.) \\
\hline Nitidulidae & Carpophilus dimidiatus (F.) \\
\hline \multirow[t]{3}{*}{ Tenebrionidae } & Tribolium castaneum (Herbst) \\
\hline & Latheticus oryzae Waterhouse \\
\hline & Cynaeus angustus (LeConte) \\
\hline Curculionidae & Sitophilus zeamais Motschulsky \\
\hline \multicolumn{2}{|l|}{ Lepidoptera } \\
\hline \multirow[t]{2}{*}{ Pyralidae } & Cadra cautella (Walker) \\
\hline & Plodia interpunctella (Hübner) \\
\hline Gelechiidae & Sitotroga cerealella (Olivier) \\
\hline \multicolumn{2}{|l|}{ Hymenoptera } \\
\hline Braconidae & Bracon hebetor Say \\
\hline Pteromalidae & $\begin{array}{l}\text { Anisopteromalus calandrae (Howard) } \\
\text { Choetopsila elegans Westwood }\end{array}$ \\
\hline \multirow[t]{2}{*}{ Bethylidae } & Holepyris sylvanidis Brèthes \\
\hline & Cephalonomia waterstoni Gahan \\
\hline
\end{tabular}

trated by the profile of grain condition at $46 \mathrm{mo}$ storage time (Fig. 1). The grain showed no evidence of heating, and moisture content changed little during the first 46 mo of storage. The mean $\pm \mathrm{SE}$ of moisture determinations made during this period was $14.46 \pm 0.09 \%$. The large surface area and shallow depth of the bulk probably prevented increase in moisture from insect activity. Moisture readings were discontinued at 53 mo when the kernels became so light that the test cell of the moisture meter would no longer hold the required 250-g sample.

The insect fauna of the grain bulk included at least 12 granivorous species belonging to three orders (Psocoptera, Coleoptera, Lepidoptera) and five species of parasitic Hymenoptera (Table 1). The Psocoptera were not identified and may have been represented by more than one species; because of their small size and large numbers, they were impossible to separate and count accurately and are not considered. At least some of the species classified as granivorous are opportunists that feed on living and dead insects and on fungi, as well as grain. Bracon hebetor Say is a parasite of various moth larvae, including Cadra cautella and Plodia interpunctella Hübner. Sitotroga cerealella (Olivier) also has been reported as a host (Krombein et al. 1979), but this seems unlikely and, as far as we know, has not been confirmed. Anisopteromalus calandrae (Howard) and Choetopsila elegans parasitize the larvae of various beetles including Sitophilus zeamais (Motschulsky) (Williams \& Floyd 1971, Krombein et al. 1979). Holepyris sylvanidis Brèthes apparently attacks the larvae of various beetle species that occur in stored grain (Evans 1978). Cephalonomia waterstoni Gahan is a larval parasite of Cryptolestes species (Finlayson 1950).

Temporal changes in the abundance of insects within the grain mass are illustrated in Fig. 2. The maximum abundance and maximum relative abundance attained by each species are given in Table 2 with the storage times at which these levels were reached. The chronology of relative abundance maxima provides a good indication of the order of succession. Nine species attained dominance during the storage period. Changes in the relative abundance of these species with increasing storage time and their periods of dominance are shown in Fig. 3-6. Fig. 7 illustrates the species composition of the insect population at selected points in the succession.

The total insect population curve (Fig. 2) can be divided into five major phases of growth and decline as indicated. Many of the most pronounced minima occurred in late winter and early spring (February-April) and probably reflect cold-induced mortality. Other minima occurred in late

Table 2. Relative abundance and abundance of insect species in a stored-corn ecosystem: maximum values attained during an 8-yr period and length of storage time (in lunar months) at which they occurred

\begin{tabular}{|c|c|c|c|c|}
\hline \multirow{2}{*}{ Species } & \multicolumn{2}{|c|}{ Relative abundance ${ }^{a}$} & \multicolumn{2}{|c|}{ Abundance $^{b}$} \\
\hline & Maximum value $\pm \mathrm{SE}$ & Storage time & Maximum value $\pm \mathrm{SE}$ & Storage time \\
\hline Sitotroga cerealella & $40.4 \pm 1.5$ & 8 & $23.2 \pm 1.7$ & 44 \\
\hline Plodia interpunctella & $25.1 \pm 1.3$ & 8 & $13.3 \pm 1.3$ & 44 \\
\hline Bracon hebetor & $23.3 \pm 1.3$ & 8 & $5.1 \pm 0.9$ & 8 \\
\hline Cadra cautella & $8.8 \pm 0.9$ & 8 & $1.9 \pm 0.3$ & 8 \\
\hline Oryzaephilus surinamensis & $62.7 \pm 0.9$ & 9 & $63.5 \pm 12.5$ & 10 \\
\hline Cryptolestes ferrugineus & $72.0 \pm 0.6$ & 12 & $183.1 \pm 15.9$ & 21 \\
\hline Sitophilus zeamais & $86.4 \pm 0.3$ & 16 & $371.8 \pm 13.0$ & 18 \\
\hline Cephalonomia waterstoni & $3.5 \pm 0.2$ & 21 & $9.6 \pm 0.9$ & 21 \\
\hline Carpophilus dimidiatus & $0.2 \pm 0.1$ & 31 & $0.3 \pm 0.1$ & 14 \\
\hline Anisopteromalus calandrae & $37.1 \pm 0.7$ & 32 & $57.6 \pm 3.1$ & 19 \\
\hline Tribolium castaneum & $77.1 \pm 0.7$ & 39 & $99.2 \pm 7.3$ & 49 \\
\hline Holepyris sylvanidis & $2.0 \pm 0.1$ & 59 & $5.2 \pm 0.5$ & 59 \\
\hline Latheticus oryzae & $94.3 \pm 0.6$ & 76 & $221.9 \pm 25.1$ & 60 \\
\hline Cynaeus angustus & $79.5 \pm 3.8$ & 90 & $9.5 \pm 0.8$ & 83 \\
\hline Choetopsila elegans & $5.2 \pm 1.2$ & 93 & $0.4 \pm 0.1$ & 93 \\
\hline Trogoderma inclusum & $83.3 \pm 1.0$ & 97 & $25.4 \pm 6.4$ & 97 \\
\hline
\end{tabular}

${ }^{a}$ Percentage of total insect population consisting of the given species; SE estimated using the normal approximation (Cochran 1977).

${ }^{b}$ Mean population density (mean number of insects/subsample in 48400 -ml subsamples of corn). 


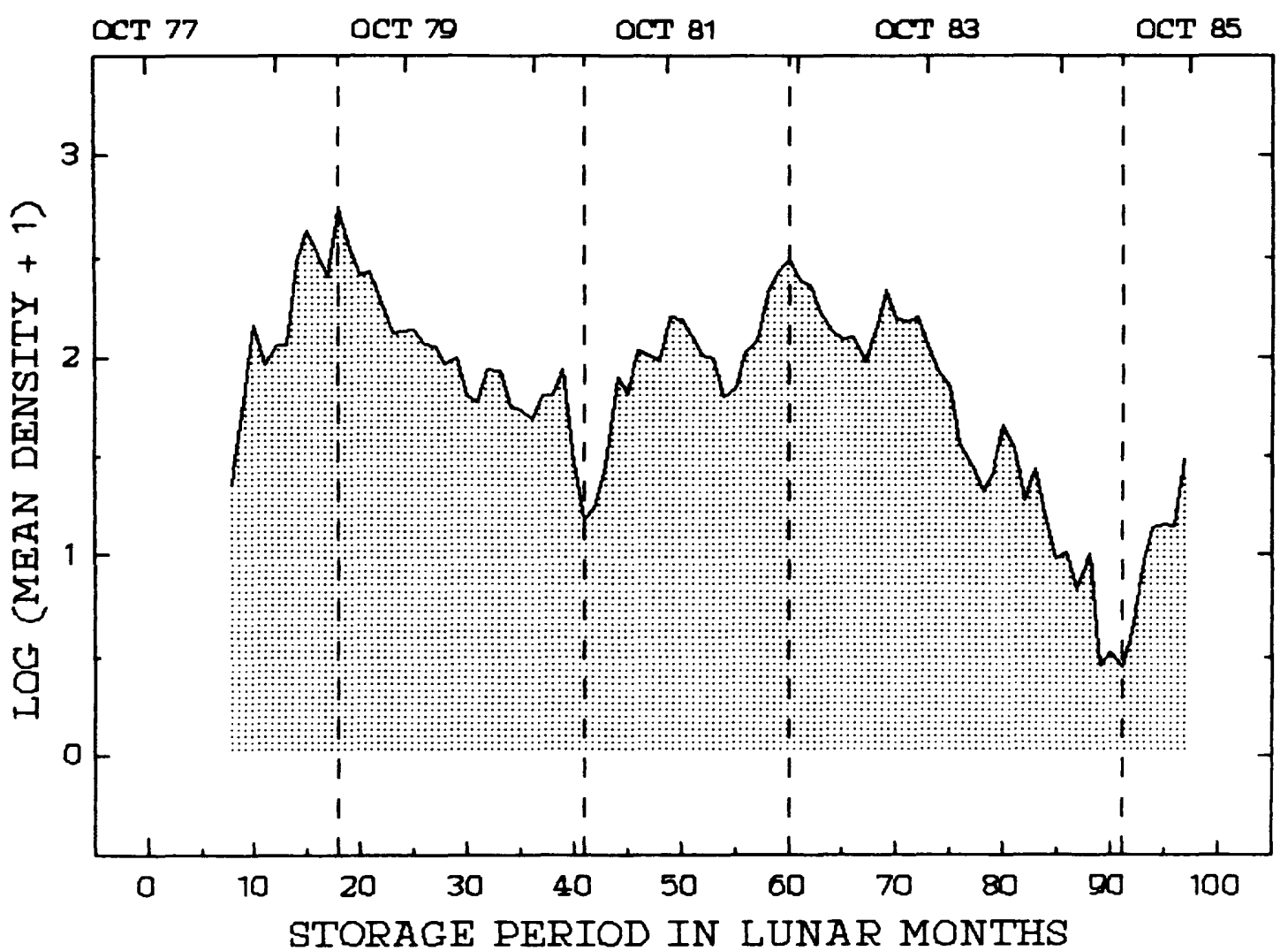

Fig. 2. Changes in abundance $[\log$ (mean population density +1$)]$ of the total insect population with storage time. Dashed vertical lines divide the population curve into major periods of growth and decline.

summer and early fall (August-October) and may have resulted from excessive heat. Arbogast \& Mullen (1987) presented temperature curves for the entire storage period. The lowest population levels (at 41 and $91 \mathrm{mo}$ ) occurred in 1981 and 1985, following the two most severe winters of the storage period (see Arbogast \& Mullen 1987, Fig. 3 and 4).

The first growth phase occupied at least the period between 8 and 18 mo. When the first sample was taken at $8 \mathrm{mo}$, the population consisted largely of moths with Sitotroga cerealella the dominant species (Fig. 7). Together, Plodia interpunctella, Cadra cautella, and $B$. hebetor constituted more than half the total number of insects. The small beetle component consisted mostly of Sitophilus zeamais with a few Cryptolestes ferrugineus, $O$. surinamensis, and Tribolium castaneum. As the population grew, O. surinamensis, Cryptolestes ferrugineus, and finally Sitophilus zeamais succeeded Sitotroga cerealella as dominant species (Fig. 3 and 4). At $18 \mathrm{mo}$, the population reached its highest level (about 549 insects per subsample) for the entire storage period and consisted mostly of beetles (Fig. 7). The small residual, represented by the missing wedge in the pie chart, included Sitotroga, Holepyris, and Plodia.
At $18 \mathrm{mo}$, the insect population entered a phase of general decline that lasted for 23 mo. Cryptolestes ferrugineus and Tribolium castaneum predominated during most of this period (Fig. 4 and 5 ). Both species were present in much lower numbers when the period ended at 41 mo than when it began, but their relative abundance had increased (Fig. 7). The proportion of Sitotroga cerealella in the insect population also had increased, although this species showed no upward trend in abundance. Sitophilus zeamais, which is less tolerant of grain damage than Sitotroga cerealella, declined drastically in numbers as the corn deteriorated and suitable breeding sites became increasingly scarce (Arbogast \& Mullen 1987). Although its population showed additional peaks, none of these approached the level observed at $18 \mathrm{mo}$. The minor peaks at 31 and 38 mo in Fig. 2 correspond to maxima in the Sitophilus zeamais population, and in fact, Sitophilus was the most abundant species at 31 mo (Fig. 4). The prevalence of Anisopteromalus calandrae at 32 mo (Fig. 5) suggests a high level of parasitism, which may have contributed to the decline of the weevil population.

The second growth phase extended from 41 to 60 mo. At 41 mo, Tribolium castaneum, Cryptolestes ferrugineus, and Sitotroga cerealella ac- 

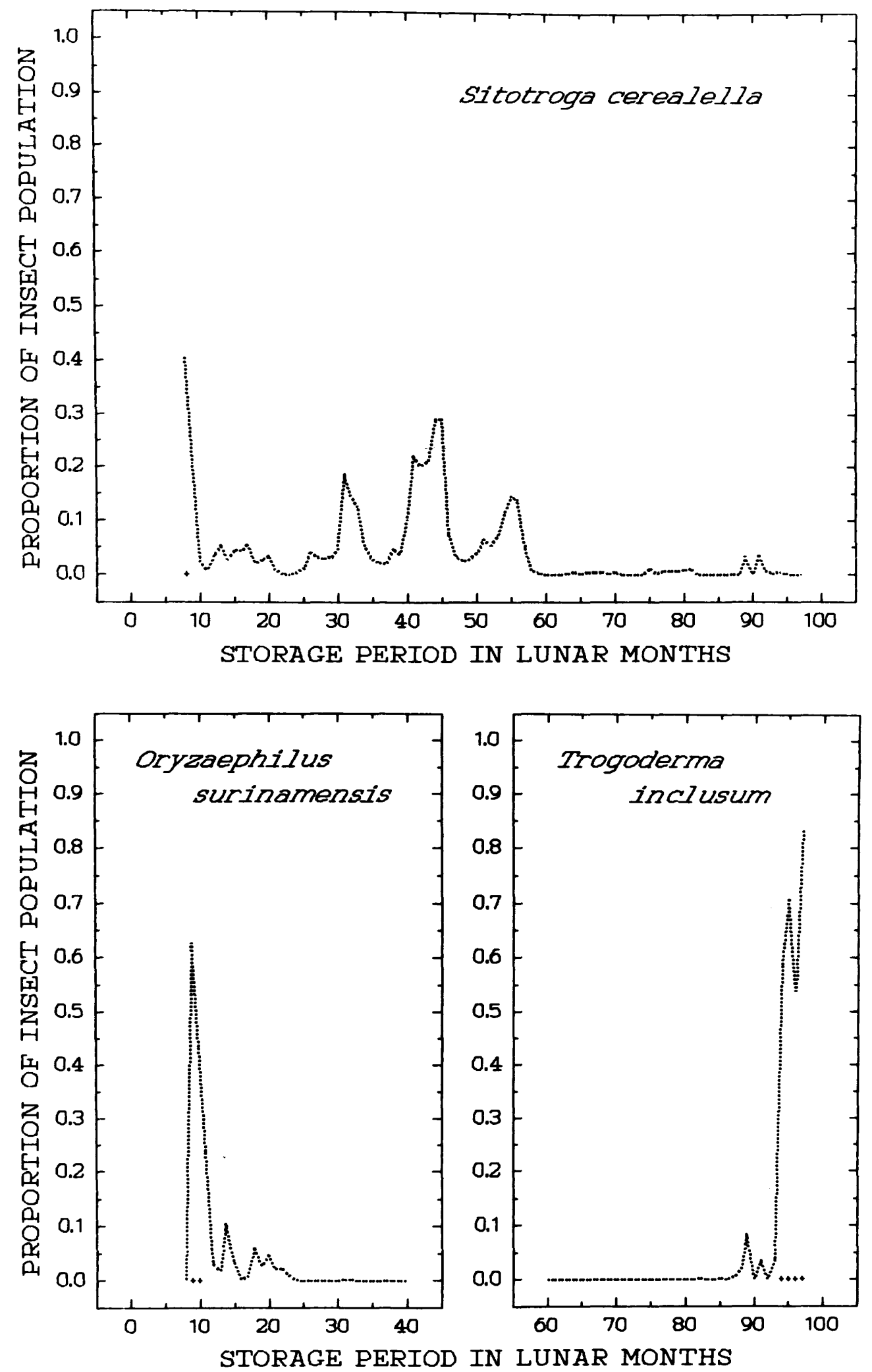

Fig. 3. Changes in relative abundance of $S$. cerealella, $O$. surinamensis, and $T$. inclusum with storage time. Plus signs below curves indicate periods of dominance. 

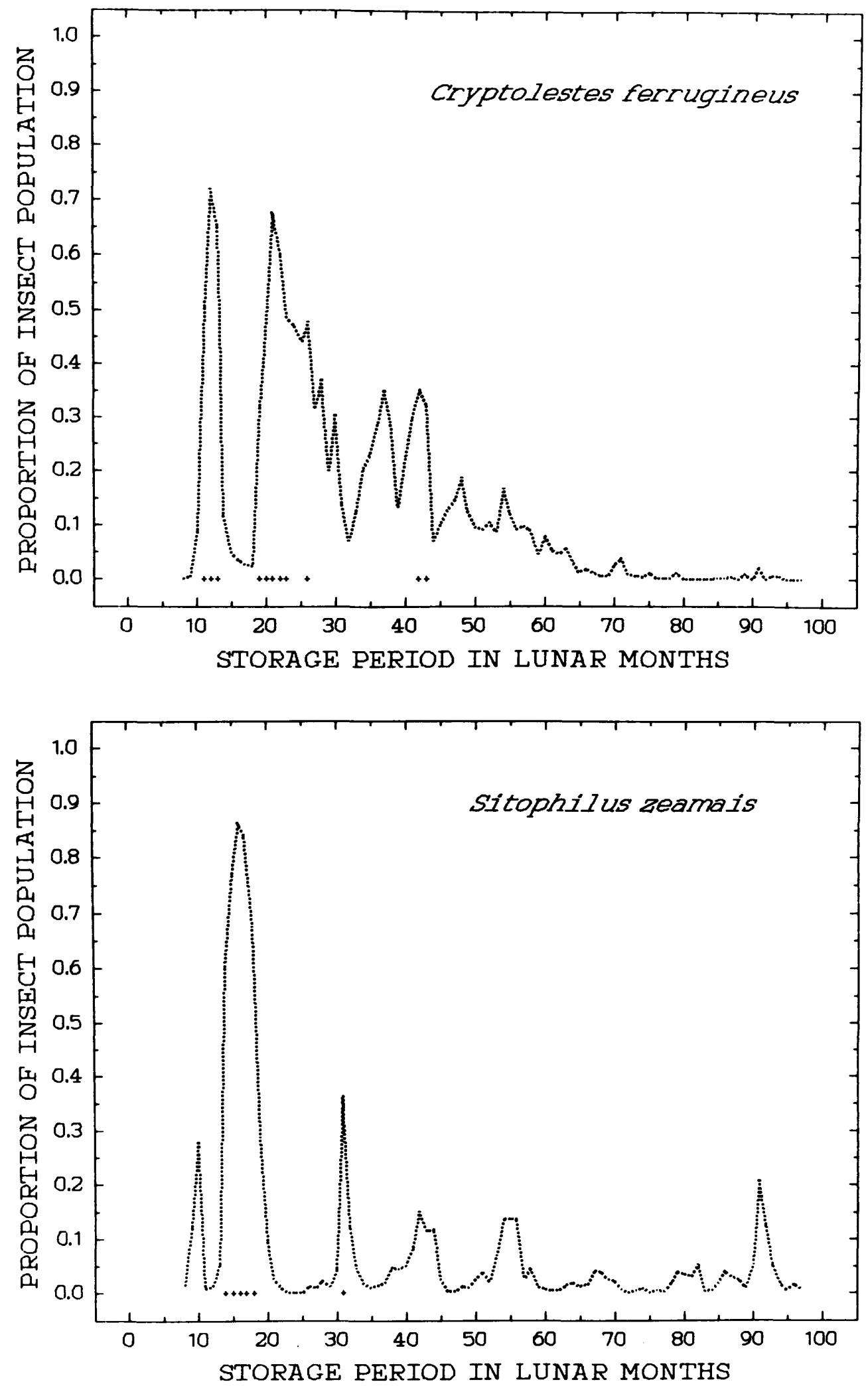

Fig. 4. Changes in relative abundance of $C$. ferrugineus and $S$. zeamais with storage time. Plus signs below curves indicate periods of dominance. 

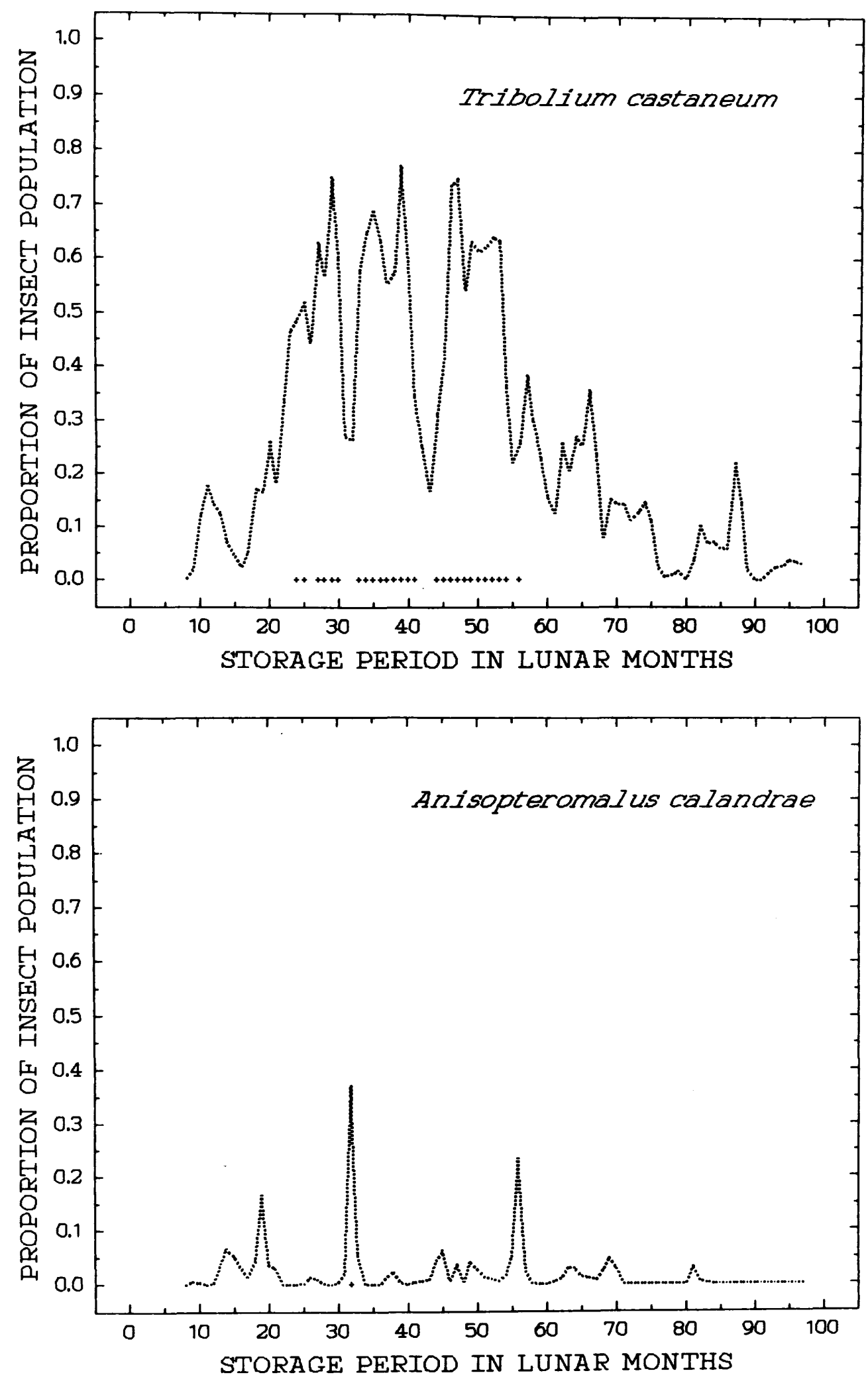

Fig. 5. Changes in relative abundance of T. castaneum and A. calandrae with storage time. Plus signs below curve indicate periods of dominance. 

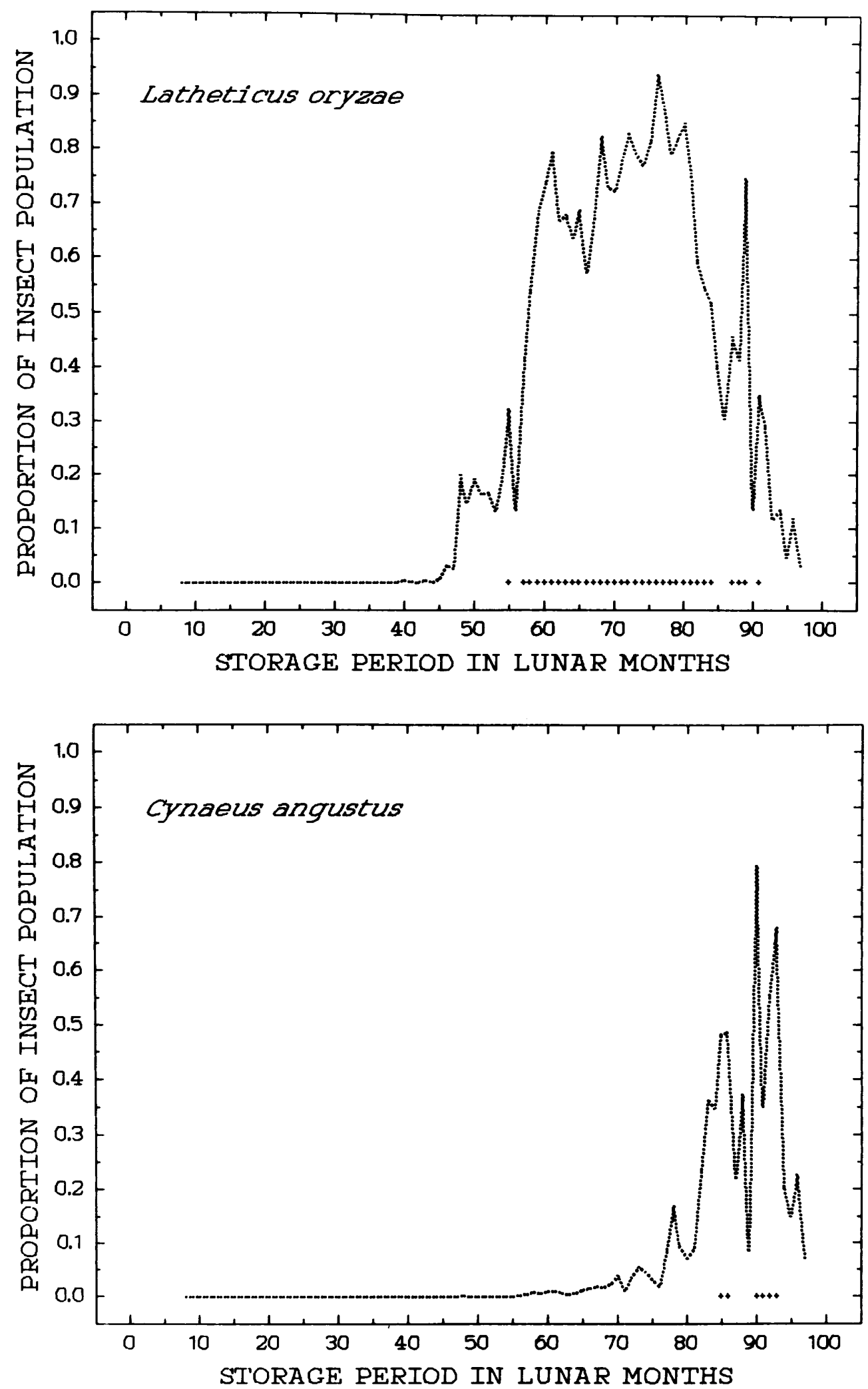

Fig. 6. Changes in relative abundance of $L$. oryzae and C. angustus with storage time. Plus signs below curve indicate periods of dominance. 


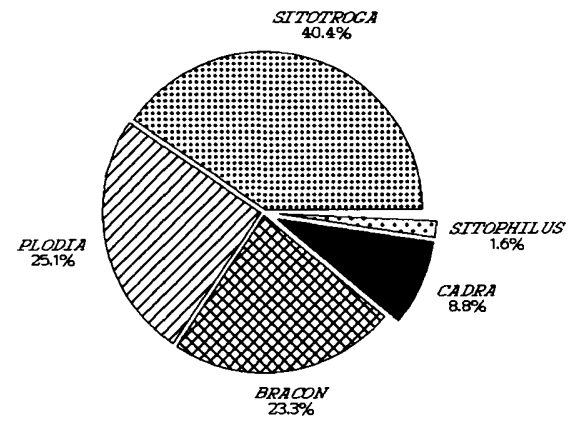

8 MONTHS

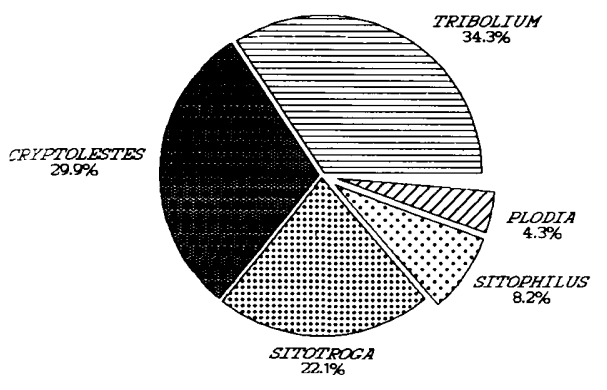

41 MONTHS

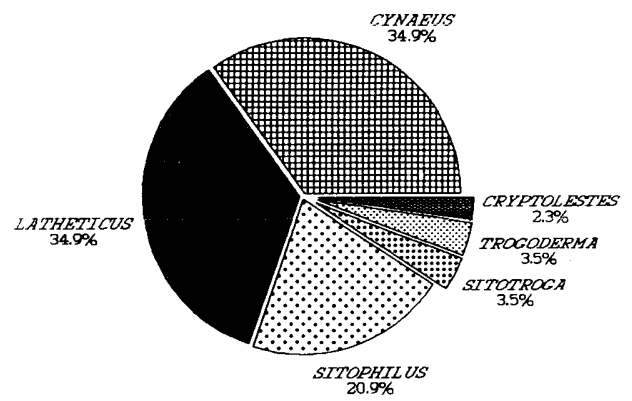

91 MONTHS

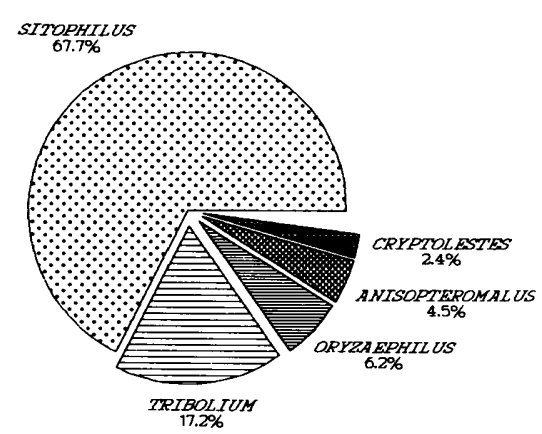

18 MONTHS

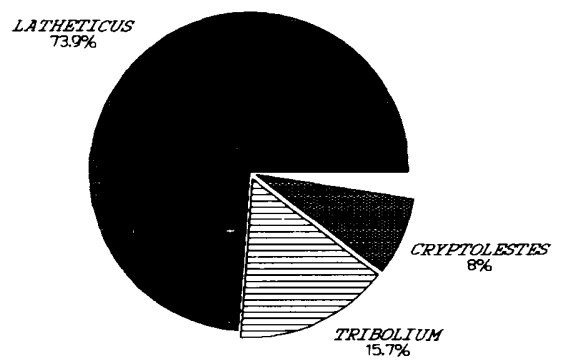

60 MONTHS

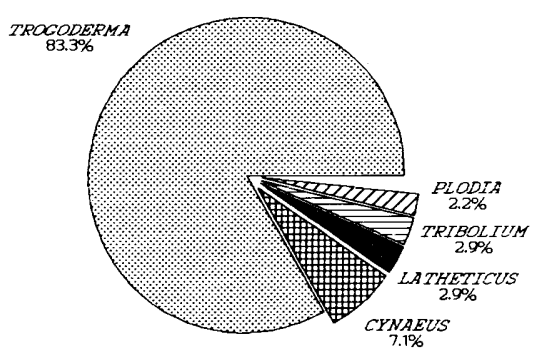

97 MONTHS

Fig. 7. Species composition of the insect population when the first and last samples were taken and at end points of major periods of population growth and decline.

counted for most of the population, although there were significant numbers of Sitophilus zeamais and $P$. interpunctella (Fig. 7). The remainder consisted of Anisopteromalus calandrae, Cadra cautella, $L$. oryzae, and Cephalonomia waterstoni. Except for a short period near the beginning of this phase, Tribolium castaneum remained the most abun- dant species until 55 mo storage time (Fig. 5). The minor valley at this point in the population curve (Fig. 2) corresponds with a minimum point in the Tribolium castaneum population and approximately with transfer of dominance to $L$. oryzae (Fig. 6). Although Tribolium increased again in numbers, it did not attain dominance after 56 mo. 
By the end of the second growth phase, Latheticus constituted nearly three-fourths of the insect population (Fig. 7). Most of the remainder consisted of Tribolium castaneum and Cryptolestes ferrugineus, but there were small numbers of Cynaeus angustus, Sitophilus zeamais, H. sylvanidis, Anisopteromalus calandrae, Trogoderma inclusum, Cephalonomia waterstoni, Carpophilus dimidiatus, and Plodia interpunctella. This was the greatest number of species observed in any one sample up until that time, although it was equaled in several other samples taken over the next 14 mo.

At $60 \mathrm{mo}$, the insect population began a second phase of general decline that carried it to its lowest level (1.8 insects per subsample) for the storage period. The abundance of $L$. oryzae decreased during this period, although its relative abundance continued to increase up to $70 \mathrm{mo}$, and it maintained its dominance throughout most of the period (Fig. 6). Cynaeus angustus increased in relative abundance and showed brief periods of dominance toward the end of the period (Fig. 6). At $91 \mathrm{mo}$, $C$. angustus and $L$. oryzae shared dominance and Trogoderma inclusum had emerged as a significant component of the population (Fig. 7).

The final growth phase, which began at 91 mo and was still in progress when observations were terminated, was characterized by an increase in numbers and relative abundance of Trogoderma inclusum (Fig. 3). Trogoderma inclusum was the dominant species during the last 4 mo of the storage period, and when the last sample was taken at 97 mo, it constituted more than $83 \%$ of the population (Fig. 7). Cynaeus angustus, L. oryzae, Tribolium castaneum, and Plodia interpunctella accounted for about $15 \%$. The remainder consisted of Sitophilus zeamais, $H$. sylvanidis, Cryptolestes ferrugineus, and Cadra cautella.

The succession of species is summarized in Fig. 3-6. Sitotroga cerealella, O. surinamensis, Cryptolestes ferrugineus, and Sitophilus zeamais predominated during the first half of the storage period. Oryzaephilus surinamensis declined rapidly after a brief period of dominance during the first year and died out during the third. The remaining species persisted to the end of the storage period. Latheticus oryzae, Cynaeus angustus, and Trogoderma inclusum predominated during the last half of the storage period, after the grain had become heavily damaged and large quantities of frass, flour, and insect remains had accumulated. Latheticus oryzae was first detected at about $3 \mathrm{yr}$ and made up a significant proportion of the population by 4 yr. Cynaeus angustus and Trogoderma inclusum were first detected at about $4 \mathrm{yr}$, but constituted a very small portion of the population until after years 5 and 7 , respectively. Tribolium castaneum was intermediate in succession. It was a significant component of the population throughout most of the storage period, but reached its greatest proportions between 2 and $5 \mathrm{yr}$.

\section{Discussion}

The ecological succession of insect species in stored grain has been reported on several occasions. Coombs \& Freeman (1955), who examined the species composition of grain residues that had accumulated in inaccessible spaces of a granary, found that dominance by certain species was associated with the quality of the residues. Thus, the granary weevil, Sitophilus granarius (L.), or the brown house moth, Hofmannophila pseudospretella (Stainton), predominated in residues with a high proportion of whole kernels. Spider beetles, Ptinus spp., and the yellow mealworm, Tenebrio molitor $\mathrm{L}$., were most abundant in residues with less whole grain and more finely divided material. Finally, only Attagenus pellio (L.) and Scenopinus fenestralis (L.) occurred in residues of very poor quality. This relationship between residue quality and species composition can be interpreted as evidence of succession, because the various grades of residue represent stages in the continuous degradation of grain by insects.

Later work by Coombs \& Woodroffe $(1963,1968)$ demonstrated insect succession in stored wheat. The earlier of their two studies involved two small bulks (6 kg each) of artificially infested wheat stored in glass tanks. The tanks were fitted with lids to prevent insects from escaping and to reduce the chance of unplanned infestation. The wheat remained relatively dry, and because it formed only very shallow layers in the storage tanks, there was little heating from insect activity. Sitophilus granarius was dominant during the first $2 \mathrm{yr}$ of the experiment. It then died out and was succeeded by Ptinus tectus Boieldieu, which was the predominant species for the next $3 \mathrm{yr}$. As P. tectus declined, Attagenus pellio became dominant and was the only species surviving after $7 \mathrm{yr}$. A similar succession of $S$. granarius by $P$. tectus was noted by Hunter (1965) in wheat residues left in a closed flour mill.

In their later study, Coombs \& Woodroffe (1968) followed changes in species composition of insect populations in two bulks ( $500 \mathrm{~kg}$ each) of wheat over a 10-yr period. The grain was held in two bunkers in a brick storage building and was deep enough to allow heating. Conditions in the building were damp, so fungal and bacterial decay took place. Seven species of insects (Sitophilus granarius, P. tectus, Ptinus pusillus Sturm, O. surinamensis, Ahasverus advena (Waltl), Hofmannophila pseudospretella, and Attagenus pellio) were introduced, and many other species gained access to the grain fortuitously. Sitophilus granarius increased during the first year and reached peak numbers during the second, after which it showed a fluctuating decline and died out during the ninth year. Oryzaephilus surinamensis peaked during the second and third years, then declined sharply and disappeared during the seventh year. Hofmannophila pseudospretella remained at a rela- 
tively low level during the first $4 \mathrm{yr}$ and then increased markedly; it began a gradual decline during the eighth year and had died out by the end of the tenth. The whiteshouldered house moth, Endrosis sarcitrella (L.), invaded the grain bulks early in the study, peaked during the second and third years and then declined to a very low level; it was not detected after the eighth year. The tineid moth Viditinea fuscipunctella (Haworth), which first appeared in small numbers during the fourth year, increased markedly during the eighth and peaked during the ninth; it was still abundant when the study ended. Ptinus tectus, P. pusillus, and Attagenus pellio never reached high numbers, and only $P$. tectus survived to the end of the study. Ahasverus advena died out during the first winter.

Sinha \& Wallace (1966), who studied the ecology of hot spots (portions of a grain bulk in which temperature has been raised well above that of the surrounding grain by the metabolism of insects or microorganisms) in stored oats, found that a series of arthropod communities developed and replaced one another at short intervals as the hot spots developed and then cooled. These transitory communities consisted of $O$. surinamensis, Cryptolestes ferrugineus, Ahasverus advena, Cryptophagus sp., and various species of mites. Oryzaephilus surinamensis was dominant early in hot spot development (January) and C. ferrugineus predominated in March, just before cooling began.

As might be expected, the species composition of successional communities differs from one climatic region to another and from commodity to commodity. Climate determines the species that are available to invade a grain bulk and influences the microclimate of the bulk itself, especially if the bulk is small. Much of the difference between the communities observed in earlier studies and those observed in our study can probably be attributed to climatic differences. The grain bulks and residues studied by Coombs \& Freeman (1955), Coombs \& Woodroffe $(1963,1968)$, and Hunter (1965) were all located in unheated buildings in England, which has a marine climate with cool summers (Trewartha 1954). The grain studied by Sinha \& Wallace (1966) comprised two bulks, each stored for one winter in a machine shed at Poplar Point, Manitoba (humid continental climate with cool summers). Hot spots can develop quickly under winter conditions in Canada, and the heating process causes a rapid deterioration of the grain (Sinha 1961) accompanied by rapid changes in the associated arthropod fauna. In contrast to these earlier studies, the grain in our study was stored in a humid subtropical climate.

Despite climatic differences and differences in commodity, there are similarities and parallels in the succession we observed and that observed by Coombs \& Woodroffe (1963, 1968). In both studies, O. surinamensis peaked during the early stages of succession, then declined rapidly and eventually died out. However, in our study this species peaked a year earlier and disappeared more rapidly; its rapid extinction may have been caused by the presence of large numbers of Tribolium castaneum, which preys heavily on $O$. surinamensis in cracked corn (LeCato 1975a). Sitophilus granarius tends to replace S. zeamais and Sitophilus oryzae (L.) in cooler climates. The population changes in S. granarius observed by Coombs and Woodroffe paralleled those we observed in S. zeamais. Both species reached maximum numbers early and then showed a long fluctuating decline. There is also a parallel between the earlier study of Coombs \& Woodroffe (1963) and ours with respect to the behavior of the dermestid species. These beetles are scavengers that feed on a wide variety of plant and animal materials. Trogoderma inclusum and Attagenus pellio became dominant late in the succession, after the grain had become severely damaged and large amounts of frass and insect remains had accumulated. The tineid moth $N$. fuscipunctella, which is also a scavenger, filled this position in the later study of Coombs \& Woodroffe (1968).

There have been no other long-term studies of stored corn to which our study can be related. However, there have been several surveys of corn storages that provide some conception of bin to bin variation in species composition (at least during the first few years of storage), and these provide a useful basis for comparison. Horton (1981) sampled farm-stored grain and soybeans (including more than 550,000 bushels of corn) on 51 farms in South Carolina. A survey of farmers indicated that the sampled corn had been in storage for an average of $7.3 \mathrm{mo}$. Of 28 species detected, 6 of the 10 most common species (Sitophilus zeamais, Tribolium castaneum, O. surinamensis, Sitotroga cerealella, Plodia interpunctella, and Cryptolestes ferrugineus) also were present in significant numbers during the early stages (8-18 mo) of our study (Fig. 7).

Species that became prevalent late in our study were either not detected by the survey or were found infrequently ( $L$. oryzae). Although Trogoderma inclusum was not detected, two other dermestid species, Attagenus megatoma (F.) and Anthrenus verbasci (L.), were found in a small percentage of infested corn. Cynaeus angustus was not detected in Horton's survey, but Barak et al. (1981) found this species in $51.2 \%$ of 1 -yr-old corn storages sampled in Minnesota. They noted that local pockets of high moisture and damaged corn may have contributed to infestation of some bins, and in another survey, they found that the incidence of infestation increased with storage timemore than $50 \%$ of bins containing 3-yr-old corn were infested. In a study of corn stored on farms in Georgia, Alabama, and Mississippi, Eden (1967) took samples at harvest and during the first year of storage. He recorded 17 species, of which $\mathrm{Si}$ tophilus oryzae and Tribolium castaneum were the most abundant. Only five of the species observed in our study (Sitotroga cerealella, Carpoph- 
ilus dimidiatus, Plodia interpunctella, Tribolium castaneum, and $O$. surinamensis) were detected.

To some extent, the species composition of a storage insect infestation is a matter of chance, determined by the species available in the local area, and so too is the series of successional communities observed at a particular site. The species that become dominant at various stages of succession may all be present at the time of storage (Coombs \& Woodroffe 1963), or they may invade the grain bulk over a period of time. This differs somewhat from the generalization made by Price (1984, p. 40) that ecological succession "occurs at any site because organisms arrive at different times and, once established, they alter the living conditions for themselves and other organisms, benefiting some and forcing others into local decline and extinction."

There are three possible routes through which insects invade stored grain: infestation of grain in the field, followed by passive movement with harvested grain into storage; dispersal from grain residues and other refuges inside storage structures into newly stored grain; and immigration from various outside sources such as unharvested grain in the field, grain residues and other plant debris, and nests of birds, rodents, bees, and wasps (Linsley 1944). Grain residues provide microhabitats in which insects can breed. The insect communities of these residues may represent early or late stages of succession, depending on the age and condition of the residue. Insects can move from residues into stored grain at any time, but their survival and rate of population growth in the bulk will depend on their particular needs in relation to grain condition. Our observations and those of Coombs \& Woodroffe $(1963,1968)$ show that some species persist in grain bulks at low population levels for long periods and then increase rapidly in numbers when the storage environment becomes favorable.

Coombs \& Woodroffe (1973) showed that insect succession in stored grain results from the combined effects of interactions between species and the influence of the insects on their environment. The manner in which these factors affect each species must be determined by experiment, but species-specific habits and requirements provide some insight.

Sitophilus zeamais and Sitotroga cerealella are primary grain pests capable of attacking sound kernels; however, many $S$. cerealella die while attempting to burrow into undamaged kernels (Simmons \& Ellington 1933) and their survival is improved if some damage already exists. Neither species reproduces well in the absence of whole kernels or large grain particles. Although there is no precise information on the oviposition requirements of Sitophilus zeamais, its life cycle and habits are similar to those of Sitophilus granarius, which feed on finely divided farinaceous material but do not oviposit in particles too small to serve as food for the development of a single larva (Back \& Cot- ton 1926). Sitotroga cerealella oviposit on ground or cracked grain as well as on whole grain, and some larvae develop successfully on these media (Ayertey 1982), although mortality is high when the grain is finely divided (Crombie 1943, Ayertey 1982). The early dominance of Sitophilus zeamais and Sitotroga cerealella observed in our study can be explained by their ability to utilize whole kernels. Their inability to breed successfully on small grain fragments accounts in part for their subsequent decline. Thus, population decrease of $\mathrm{Si}$ tophilus zeamais paralleled reduction in kernel density, as did that of Sitotroga cerealella after about 5 yr (Arbogast \& Mullen 1987). The later decline of $S$. cerealella can be attributed to its greater tolerance of grain damage.

The remaining granivorous species observed in our study are secondary pests that feed on damaged kernels and grain debris. Most cannot feed on perfectly intact grain, but even minor damage to the seed coat renders the kernels susceptible to attack (Good 1936, Fraenkel \& Blewett 1943, Rilett 1949, Khalifa \& Badawy 1955). There is some evidence that the reproductive success of these species increases with the degree of kernel damage. For example, Krall \& Decker (1946) found that Cynaeus angustus is capable of feeding on undamaged corn kernels, but development is faster and mortality is lower on cracked corn. Also, reproduction of Tribolium castaneum was higher on cracked corn than on slightly damaged kernels and higher still on cornmeal (LeCato \& McCray 1973).

Almost any grain bulk contains enough broken kernels to permit infestation by secondary pests, but population growth of these species is enhanced by the damage that accrues from feeding by primary pests such as Sitophilus zeamais and Sitotroga cerealella, which are especially effective in reducing whole kernels to fragments and dust. The beneficial relationship between primary and secondary pests has been demonstrated experimentally by LeCato (1975c) and Ciesielska (1978).

Secondary pests often supplement their cereal diet through predation and by feeding on dead insects, habits that can be significant in determining successional change. Barnes \& Simmons (1952) reported that $O$. surinamensis reduced populations of Plodia interpunctella by feeding on its eggs. Tribolium castaneum has been shown to suppress other species by preying aggressively on their immature stages (LeCato 1975b), and thereby it stimulates its own population growth (LeCato \& Flaherty 1973). The timing of successional changes observed in our study and the experimental work cited above suggest predation by Tribolium castaneum as a probable factor in the decline of Plodia interpunctella, O. surinamensis, and Cryptolestes ferrugineus; they also suggest that predation by $O$. surinamensis may have contributed to the decline of Plodia interpunctella.

It is probable that environmental conditioning also played a major role in population decline, at 
least during the last quarter of the storage period. Conditioning of grain results from nutritional depletion and accumulation of waste products such as frass and cast skins. It is known to produce population decline in Tribolium species, largely by reducing fecundity but also by prolonging larval development and increasing larval mortality (Allee et al. 1949). Reduction in fecundity is inversely proportional to the degree of conditioning, and even a slight amount lowers the oviposition rate. Sitophilus granarius is also affected adversely by conditioning, although the mixture of grain hulls, small fragments of endosperm, and frass produced in wheat by the activities of this insect is an excellent diet for several other species of stored-product insects (Coombs \& Woodroffe 1964).

The rapid increase in numbers of Trogoderma inclusum observed during the last few months of our study is consistent with its feeding habits and suggests that it is at least tolerant of conditioning by other species, if not, in fact, favored by it. Trogoderma inclusum exists outdoors as a scavenger, feeding on cast skins and insect remains (Hinton 1945). In storages, it attacks a wide range of grain and cereal products but does not do well on whole grain (Strong 1975).

Much remains to be learned about insect succession in stored grain. However, we can make a few generalizations on the basis of information now available. (1) Successional change results from the combined action of species-specific responses to grain degradation (breakdown of kernels, accumulation of insect remains, and conditioning) and interactions among species. Grain degradation is largely the result of insect activity, although other organisms, such as fungi, can be significant in some situations. (2) The species mix involved in succession at a particular site depends on what species are available in the area. This is influenced by climatic and other factors but is partly a matter of chance. (3) The dominant species in a series of successional communities often exist at very low levels in a grain bulk long before conditions favor their dominance. In the extreme case, all the dominants are present at the time of storage.

\section{Acknowledgment}

Margaret Carthon was a participant in this study from its inception to its completion, and we are deeply grateful for her untiring efforts in collecting and tabulating data. We are also indebted to Patricia Lang, Alice Miller, Linda Robertson, Richard Byrd, and Tayloranne Reedy, who provided assistance in various phases of the work. Specimens of Carpophilus dimidiatus were identified by W. A. Connell, Beneficial Insects Research Laboratory, USDA, Newark, Del. Cryptolestes ferrugineus and $C y$ naeus angustus were identified by T. J. Spilman, Trogoderma inclusum by J. M. Kingsolver, Anisopteromalus calandrae and Choetopsila elegans by E. E. Grissell, and Holepyris sylvanidis and Cephalonomia waterstoni by A. S. Menke, Systematic Entomology Laboratory, USDA, Beltsville, Md.

\section{References Cited}

Allee, W. C., A. E. Emerson, O. Park, T. Park \& K. P. Schmidt. 1949. Principles of animal ecology. Saunders, Philadelphia.

Arbogast, R. T. \& M. A. Mullen. 1987. Dynamics of Sitotroga cerealella (Olivier) (Lepidoptera: Gelechiidae) and Sitophilus zeamais Motschulsky (Coleoptera: Curculionidae) populations in a small bulk of shelled corn. Res. Popul. Ecol. (Kyoto) 29: 1-15.

Ayertey, J. N. 1982. Development of Sitotroga cerealella on whole, cracked or ground maize. Entomol. Exp. Appl. 31: 165-169.

Back, E. A. \& R. T. Cotton. 1926. The granary weevil. Bulletin of the USDA 1393.

Barak, A. V., F. V. Dunkel \& P. K. Harein. 1981. Emergence of the larger black flour beetle as a major pest of farm-stored grain in Minnesota. J. Econ. Entomol. 74: 726-729.

Barnes, D. F. \& P. Simmons. 1952. Competition between saw-toothed grain beetle and Indian-meal moth. J. Econ. Entomol. 45: 750-751.

Ciesielska, Z. 1978. Interactions among populations of granary beetles (Sitophilus granarius L., Rhizopertha dominica $\mathrm{F}$. and Oryzaephilus surinamensis L.). Polish Ecological Studies 4: 5-44.

Cochran, W. G. 1977. Sampling techniques. John Wiley, New York.

Coombs, C. W. \& J. A. Freeman. 1955. The insect fauna of an empty granary. Bull. Entomol. Res. 46: 399-417.

Coombs, C. W. \& G. E. Woodroffe. 1963. An experimental demonstration of ecological succession in an insect population breeding in stored wheat. J. Anim. Ecol. 32: 271-279.

1964. The influence of food condition on the longevity of Sitophilus granarius (L.) (Col., Curculionidae). Entomol. Mon. Mag. 99: 145-146.

1968. Changes in the arthropod fauna of an experimental bulk of stored wheat. J. Appl. Ecol. 5: 563574.

1973. Evaluation of some of the factors involved in ecological succession in an insect population breeding in stored wheat. J. Anim. Ecol. 42: 305-322.

Crombie, A. C. 1943. The development of the Angoumois grain moth (Sitotroga cerealella Oliv.). Nature 152: 246.

Eden, W. G. 1967. Insect damage to corn in three southeastern states at the time of harvest and in farm storage. USDA Marketing Research Report 792.

Evans, H. E. 1978. The Bethylidae of America north of Mexico. Memoirs of the American Entomological Institute (Ann Arbor) 27.

Finlayson, L. H. 1950. Host preference of Cephalonomia waterstoni Gahan, a bethylid parasitoid of Laemophloeus species. Behaviour 2: 275-316.

Fraenkel, G. \& M. Blewett. 1943. The natural foods and the food requirements of several species of stored products insects. Trans. Roy. Entomol. Soc. London 93: $457-490$

Good, N. E. 1936. The flour beetles of the genus Tribolium. USDA Technical Bulletin 498.

Hinton, H. E. 1945. A monograph of the beetles associated with stored products, vol. I. British Museum (Natural History), London.

Horton, P. M. 1981. Identification and control of onfarm stored product insect problems in South Carolina. Ph.D. dissertation, Auburn University, Auburn, Alabama. 
Hunter, F. A. 1965. The fate of the insect mite fauna in a derelict flour mill in the English midlands, pp. 644-646. In Proceedings, XII International Congress of Entomology, London (1964).

Khalifa, A. \& A. Badawy. 1955. The effect of nutrition on the biology of Tribolium confusum Duv., Tribolium castaneum Hbst., and Latheticus oryzae Waterh. Bull. Soc. Entomol. Egypte 39: 337-350.

Krall, J. L. \& G. C. Decker. 1946. The biology of Cynaeus angustus Lec. Iowa State Coll. J. Sci. 20: 384-402.

Krombein, K. V., P. D. Hurd, Jr., D. R. Smith \& B. D. Burks. 1979. Catalogue of Hymenoptera in America north of Mexico. Smithsonian Institution Press, Washington, D.C.

LeCato, G. L. 1975a. Predation by red flour beetle on sawtoothed grain beetle. Environ. Entomol. 4: 504506.

1975b. Interactions among four species of storedproduct insects: a multifactorial study. Ann. Entomol. Soc. Am. 68: 677-679.

1975c. Species composition influencing insect population growth and weight loss of stored rice, wheat, and corn. J. Kansas Entomol. Soc. 48: 224-231.

LeCato, G. L. \& B. R. Flaherty. 1973. Tribolium castaneum progeny production and development on diets supplemented with eggs or adults of Plodia interpunctella. J. Stored Prod. Res. 9: 199-203.

LeCato, G. L. \& T. L. McCray. 1973. Multiplication of Oryzaephilus sp. and Tribolium sp. on 20 natural product diets. Environ. Entomol. 2: 176-179.

Linsley, E. G. 1944. Natural sources, habitats, and reservoirs of insects associated with stored products. Hilgardia 16: 187-224.

Price, P. W. 1984. The concept of the ecosystem, pp 19-50. In C. B. Huffaker \& R. L. Rabb [eds.], Ecological entomology. John Wiley, New York.

Rilett, R. O. 1949. The biology of Laemophloeus ferrugineus (Steph.). Can. J. Res. D27: 112-148.

Simmons, P. \& G. W. Ellington. 1933. Life history of the Angoumois grain moth in Maryland. USDA Technical Bulletin 351 .

Sinha, R. N. 1961. Insects and mites associated with hot spots in farm stored grain. Can. Entomol. 93: 609621.

1973. Ecology of storage. Ann. Technol. Agr. 22: 351369.

Sinha, R. N. \& H. A. H. Wallace. 1966. Ecology of insect-induced hot spots in stored grain in western Canada. Res. Popul. Ecol. 8: 107-132.

Strong, R. G. 1975. Comparative studies on the biologies of six species of Trogoderma: T. inclusum. Ann. Entomol. Soc. Am. 68: 91-104.

Trewartha, G. T. 1954. An introduction to climate. McGraw-Hill, New York.

Williams, R. N. \& E. H. Floyd. 1971. Effect of two parasites, Anisopteromalus calandrae and Choetospila elegans upon populations of the maize weevil under laboratory and natural conditions. J. Econ. Entomol. 64: 1407-1408.

Received for publication 26 October 1987; accepted 25 July 1988. 